\title{
Effects of Waste Glass Powder on Compressive Strength of Concrete
}

\author{
Sudhanshu Kumar \\ Asst. Professor, Department of Civil Engineering, \\ Maharishi Arvind Institute of Engineering \& \\ Technology, Mansarovar, Jaipur, Rajasthan, India
}

\author{
Dr. Bharat Nagar \\ Asst. Professor, Department of Civil Engineering, \\ Jagannath University, \\ Jaipur, Rajasthan, India
}

\section{ABSTRACT}

In this research an attempt is made to study the effect of waste glass power in Concrete using waste glass, which is non biodegradable and not suitable to landfill. This study is carried out to use such waste materials into construction industries so that our environment is free to one of the major pollutant produced by the manufacturing industries.

The main aim of this study is to utilization of waste glass power as a partial replacement of fine aggregate. In this study the aim is to determine the percentage of glass replacement, resulting in optimal compressive strength.

Concrete nominal mix of M20 with different percentages of Glass power has been evaluated as per IS 2386(part IV) and IS 383. Waste glass powder was replace with fine aggregate in various percentages such as $5 \%, 10 \%, 15 \%, 20 \%, 25 \%, 30 \%, 35 \%, 40 \%, 45 \%$, and $50 \%$. Reference concrete mix is also made for comparative reasons.

KEYWORDS: Nominal Mix, Waste Glass power, Compressive Strength, construction industries

\section{INTRODUCTION}

Waste management has become a significant issue in today's growing society. As in India there is no such procedure to manage the waste properly it is caused a significant damage to the environment as well as the human health. Now we need some new and innovative technologies to reduce this waste so that it is used by other industries to fulfill their requirements.

Glass is an amorphous solid that has been found in various forms for thousands of years and has been manufactured for human use since 12,000 BC. Glass is one the most versatile substances on Earth, used in many applications and in a wide variety of forms, from plain clears glass to tempered and tinted varieties, and so forth. The interest of the construction community in using waste or recycled materials in concrete is increasing because of the emphasis placed on sustainable construction. Glass is an inert material which could be recycled and used many times without changing its chemical property (Aimin $\mathrm{Xu}$ and Ahmad shayam, 2004). In this present research some efforts have been made for the concrete industries so that this harmful waste can be used as useful.

Various research are carried out to use waste glass power as partial replacement of cement but there are almost no detailed investigation made so far on the performance of concrete replacing fine aggregate.

Concrete is the second largest material in the world and placed after water, the most useful for human as well as animals.

Fine aggregate is mainly finding from river and now a day's become highly expensive and scare hence there are large demand of alternative material from waste industries.

In this experimental study waste glass are collected from the local market and waste dumped areas. This waste is crushed in Los angles machine and finally convert to sand size.

\section{Purpose and methodology}

The main purpose of the study is to utilize the glass waste as a partial replacement of fine aggregate and also check the performance of glass concrete with respect to the control mix in strength consideration. The methodology is clearly understand with the help of flow diagram showing in figure no 1 

www.ijtsrd.com

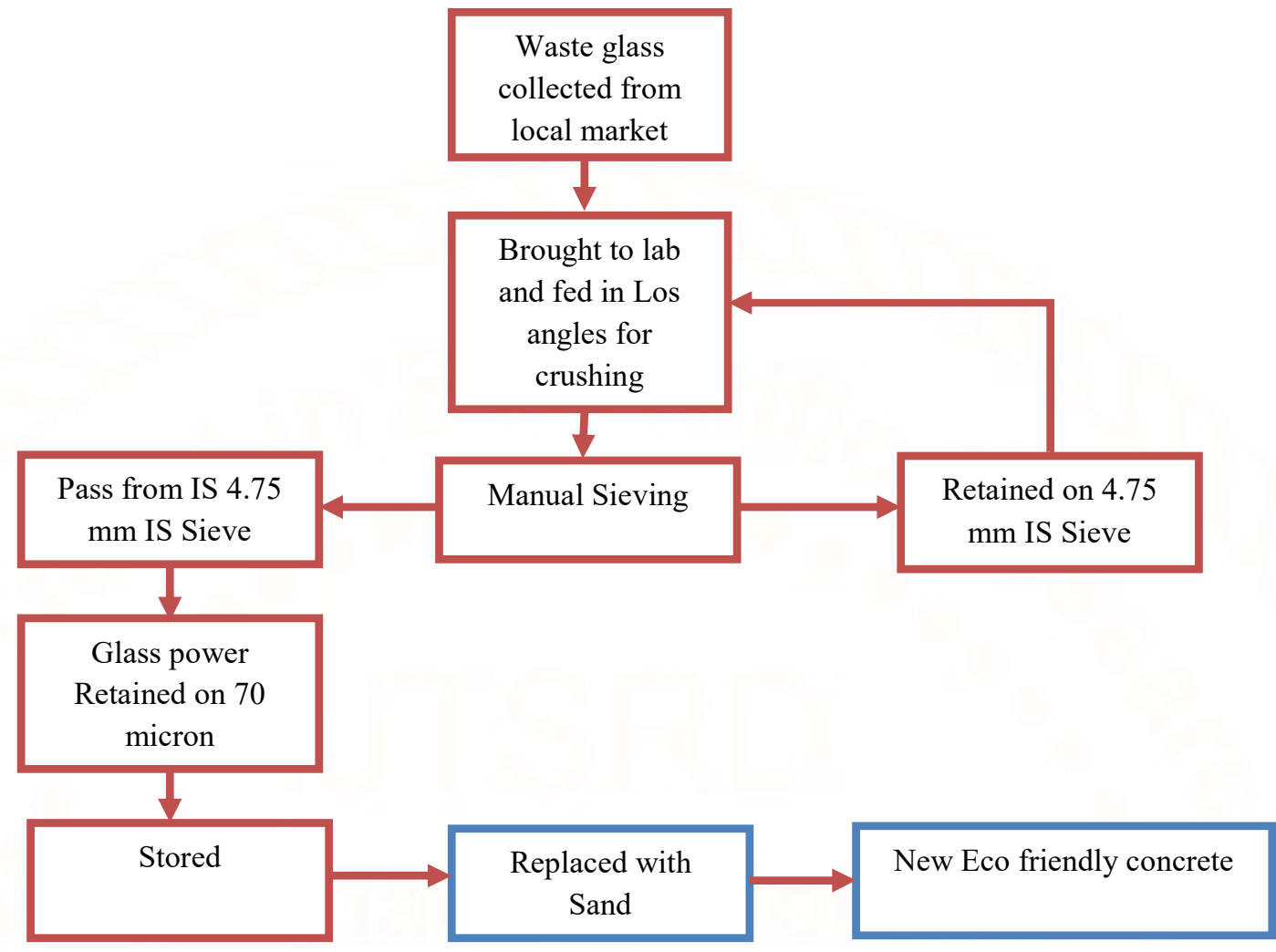

Figure 1: flow chart of methodology

\section{Experimental investigation}

Various basic tests are carried out for different materials. The most common test on concrete is the compressive strength test. This test is done to check the ability of concrete to resist the compression force. Testing of concrete cube is taken as par the guidelines given in IS 516-1959 And cube mould are taken as per the guidelines given in IS 10086-1982.

3.1 Particle size analysis of waste glass power and fine aggregate

\begin{tabular}{|c|c|c|c|c|c|c|}
\hline \multicolumn{9}{|c|}{ Particle size analysis of glass powder 1000 gm total weight } \\
\hline $\begin{array}{c}\text { S. } \\
\text { NO }\end{array}$ & $\begin{array}{c}\text { SET OF } \\
\text { SIEVE }\end{array}$ & $\begin{array}{c}\text { SIEVE } \\
\text { SIZE } \\
\text { mm }\end{array}$ & $\begin{array}{c}\text { WEIGHT } \\
\text { RETAIN } \\
\text { ED }\end{array}$ & $\begin{array}{c}\text { \% } \\
\text { RETAINED } \\
\text { gm }\end{array}$ & $\begin{array}{c}\text { CUMULATIVE } \\
\text { \% RETAINED }\end{array}$ & $\begin{array}{c}\text { CUMULATIVE WEIGHT } \\
\text { PASSSING(\% FINER) }\end{array}$ \\
\hline 1 & $4.75 \mathrm{~mm}$ & 4.75 & 16.5 & 1.65 & 1.65 & 98.35 \\
\hline 2 & $2.36 \mathrm{~mm}$ & 2.36 & 35 & 3.5 & 5.15 & 94.85 \\
\hline 3 & $1.00 \mathrm{~mm}$ & 1 & 60.5 & 6.05 & 11.2 & 88.8 \\
\hline 4 & $600 \mathrm{micron}$ & 0.6 & 215.5 & 21.55 & 32.75 & 67.25 \\
\hline 5 & $425 \mathrm{micron}$ & 0.425 & 215.5 & 21.55 & 54.3 & 29.15 \\
\hline 6 & $300 \mathrm{micron}$ & 0.3 & 165.5 & 16.55 & 70.85 & 20.55 \\
\hline 7 & $250 \mathrm{micron}$ & 0.25 & 86 & 8.6 & 79.45 & 6.5 \\
\hline 8 & $150 \mathrm{micron}$ & 0.15 & 140.5 & 14.05 & 93.5 & 0.85 \\
\hline 9 & $75 \mathrm{micron}$ & 0.075 & 56.5 & 5.65 & 99.15 & 0 \\
\hline 10 & Pan & $\ldots \ldots \ldots$. & 8.5 & 0.85 & 100 & \\
\hline & Total & & 1000 & & & \\
\hline
\end{tabular}

Table 1: sieve analysis of glass powder 
International Journal of Trend in Scientific Research and Development, Volume 1(4), ISSN: 2456-6470 www.ijtsrd.com

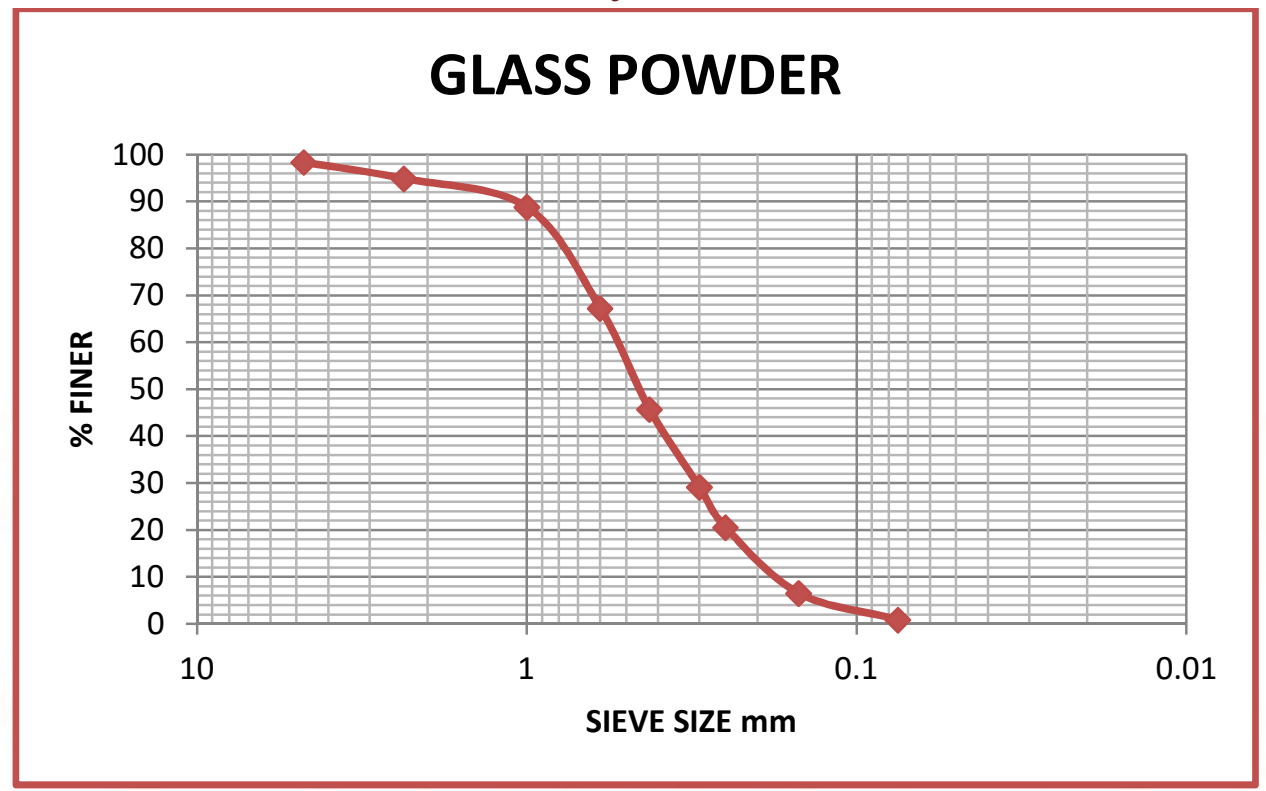

Figure 2: particle size curve of glass powder

\begin{tabular}{|l|l|l|l|l|l|l|}
\hline \multicolumn{7}{|c|}{ Particle size analysis of sand 1000 gm total weight } \\
\hline $\begin{array}{l}\text { S } \\
\text { No }\end{array}$ & $\begin{array}{l}\text { Set of } \\
\text { sieve }\end{array}$ & $\begin{array}{l}\text { Sieve } \\
\text { size } \mathbf{m m}\end{array}$ & $\begin{array}{l}\text { Weight } \\
\text { retained }\end{array}$ & $\begin{array}{l}\text { \% retained } \\
\text { gm }\end{array}$ & $\begin{array}{l}\text { Cumulative } \\
\text { \% retained }\end{array}$ & $\begin{array}{l}\text { Cumulative weight } \\
\text { passing }\end{array}$ (\% finer) \\
\hline $\mathbf{1}$ & $4.75 \mathrm{~mm}$ & 4.75 & 32 & 3.2 & 3.2 & 96.8 \\
\hline $\mathbf{2}$ & $2.36 \mathrm{~mm}$ & 2.36 & 30 & 3 & 6.2 & 93.8 \\
\hline $\mathbf{3}$ & $1.00 \mathrm{~mm}$ & 1 & 131.5 & 13.15 & 19.35 & 80.65 \\
\hline $\mathbf{4}$ & $600 \mathrm{micron}$ & 0.6 & 136.5 & 13.65 & 33 & 67 \\
\hline $\mathbf{5}$ & $425 \mathrm{micron}$ & 0.425 & 222 & 22.2 & 55.2 & 44.8 \\
\hline $\mathbf{6}$ & $300 \mathrm{micron}$ & 0.3 & 216 & 21.6 & 76.8 & 23.2 \\
\hline $\mathbf{7}$ & 250 micron & 0.25 & 81.5 & 8.15 & 84.95 & 15.05 \\
\hline $\mathbf{8}$ & $150 \mathrm{micron}$ & 0.15 & 105.5 & 10.55 & 95.5 & 4.5 \\
\hline $\mathbf{9}$ & 75 micron & 0.075 & 40.5 & 4.05 & 99.55 & 0.45 \\
\hline $\mathbf{1 0}$ & Pan & & 4.5 & 0.45 & 100 & 0 \\
\hline & Total & & $\mathbf{1 0 0 0}$ & & & \\
\hline
\end{tabular}

Table 2: sieve analysis of sand 

www.ijtsrd.com

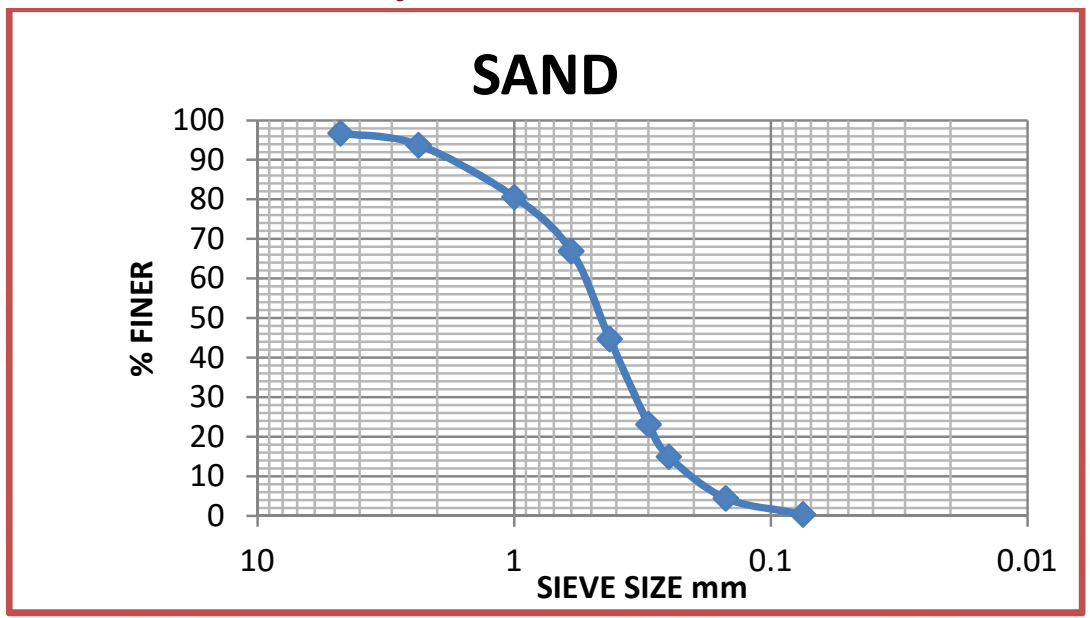

Figure 3: particle size curve of sand

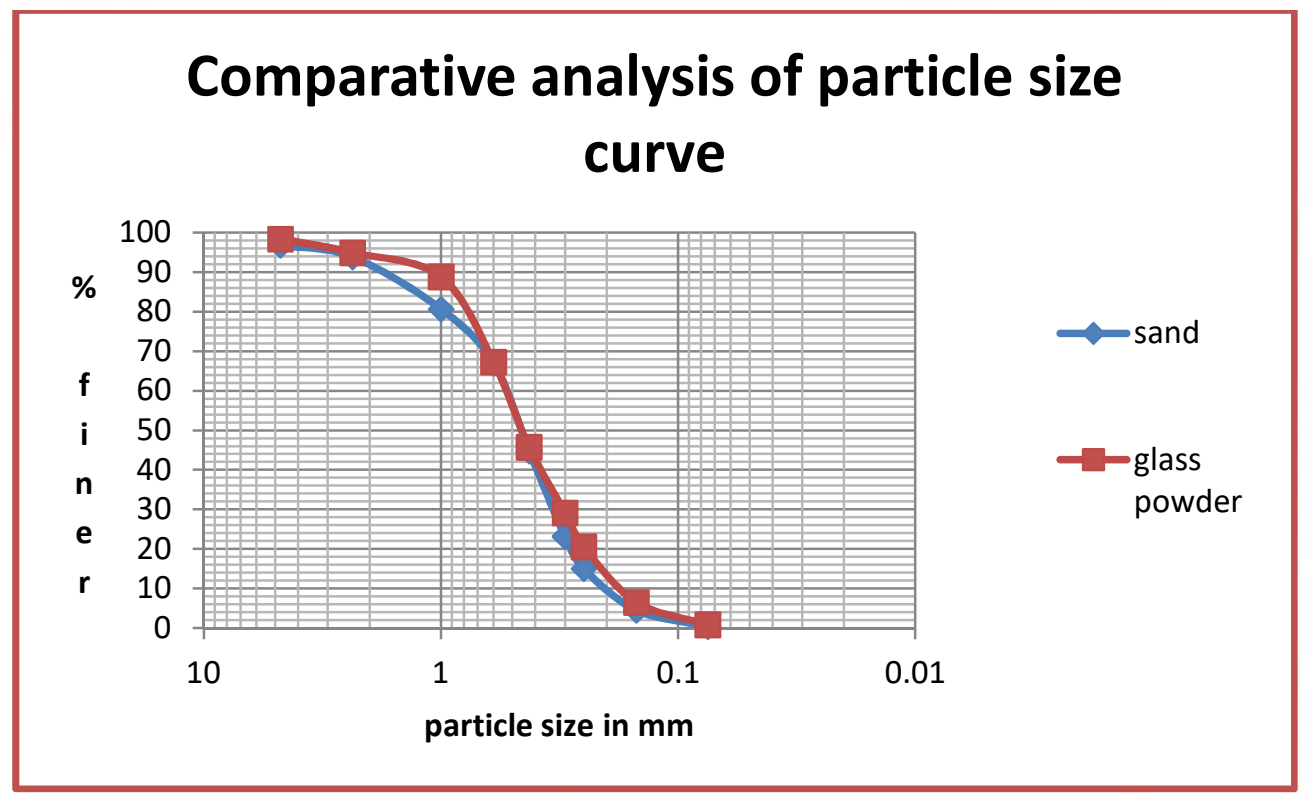

Figure 4: Comparative analysis of particle size curve

From the above curve shown in figure2, 3, and 4 it is clearly shown that both the materials are fall under the Grading Zone of II (IS: 383-1970)

\subsection{SPECIFIC GRAVITY OF WASTE GLASS POWER AND NATURAL SAND}

This test is done with reference to SP 206-7.1 and IS 2386 part IV-1963 with the help of standard pycnometer

\begin{tabular}{|l|l|l|}
\hline \multicolumn{3}{|c|}{ Specific gravity of Sand } \\
\hline s no & weight & value $(\mathrm{gm})$ \\
\hline $\mathbf{1}$ & M1 & 621.5 \\
\hline $\mathbf{2}$ & M2 & 821.5 \\
\hline $\mathbf{3}$ & M3 & 1639 \\
\hline $\mathbf{4}$ & M4 & 1514 \\
\hline
\end{tabular}

Table 3: Specific gravity of sand

\begin{tabular}{|l|l|l|}
\hline \multicolumn{3}{|c|}{ Specific gravity of Glass powder } \\
\hline s no & weight & value $(\mathrm{gm})$ \\
\hline $\mathbf{1}$ & M1 & 620 \\
\hline $\mathbf{2}$ & M2 & 820 \\
\hline $\mathbf{3}$ & M3 & 1638 \\
\hline $\mathbf{4}$ & M4 & 1514 \\
\hline
\end{tabular}

Table 4: Specific gravity of glass 
From the above data the specific gravity of sand is found 2.66 and for waste glass power it is 2.63

\subsection{Physical properties of glass powder and fine aggregate}

\begin{tabular}{|l|l|l|l|}
\hline Compositions & Name & Sand (\%) & Glass powder (\%) \\
\hline $\mathbf{S i o}_{2}$ & Silica & 81.98 & 78.13 \\
\hline $\mathbf{N a}_{2} \mathbf{O}$ & Sodium Oxide & 1.5 & 14.5 \\
\hline $\mathbf{C a O}$ & Lime & 2.8 & 11.1 \\
\hline $\mathbf{A l}_{2} \mathbf{O}_{3}$ & Alumina & 9.88 & 2.6 \\
\hline $\mathbf{M g O}$ & Magnesia & 5.2 & 1.9 \\
\hline $\mathbf{K}_{2} \mathbf{O}$ & Potassium oxide & 1.32 & 0.26 \\
\hline $\mathbf{F e}_{2} \mathbf{O}_{3}$ & Ferrous oxide & 1.18 & 0.36 \\
\hline $\mathbf{S O}_{3}$ & Sulpher trioxide & Nil & 0.11 \\
\hline $\mathbf{C r}_{2} \mathbf{O}_{3}$ & Chromium oxide & Nil & 0.02 \\
\hline $\mathbf{A l l}_{\mathbf{l}}$ other oxides & & Nil & Nil \\
\hline
\end{tabular}

Table 5: Physical properties of glass powder and fine aggregate

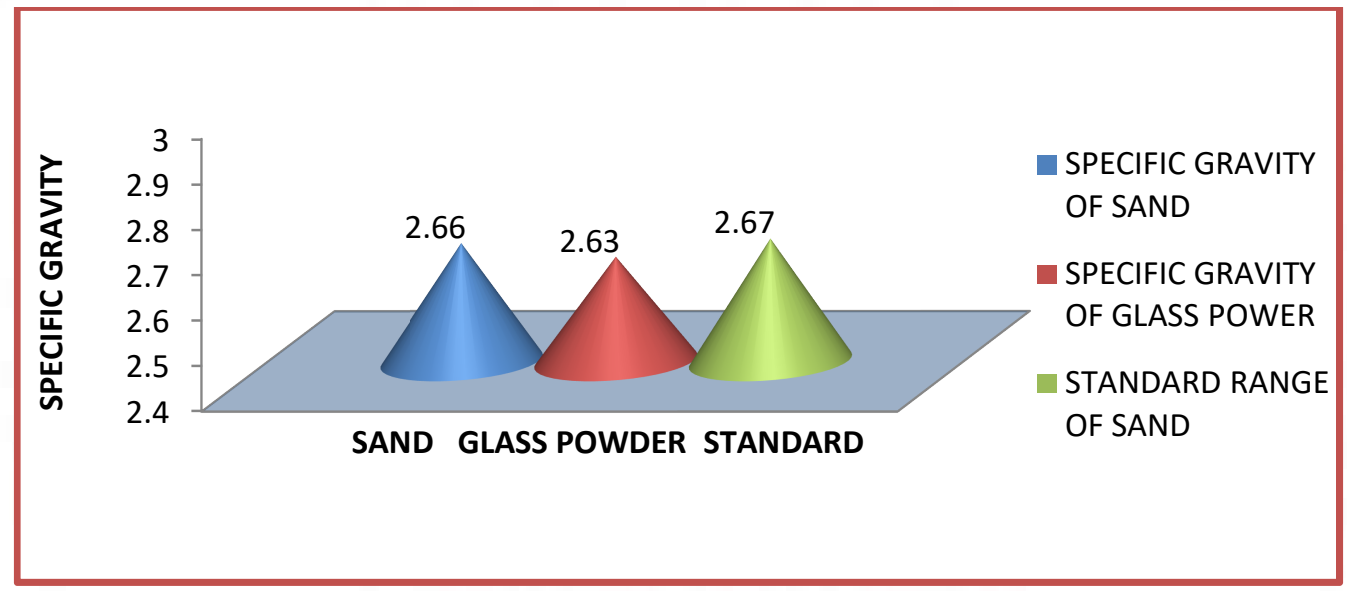

Figure 5: Comparative analysis of specific gravity

\section{Experimental Procedure}

4.1 For this study, 43 grade ordinary Portland cement were used. Graded angular aggregates of nominal size $20 \mathrm{~mm}$ and $10 \mathrm{~mm}$; and river sand confirming to zone II were used. The coarse aggregates was of angular in nature and with nominal maximum size of $20 \mathrm{~mm}$. the fine aggregate used here is in the form of river sand, and it is originate from the Banas river, Tonk district. The physical properties of both coarse and fine aggregates are conformed to requirements specified in IS 383-1970(reaffirmed 2002).

Mix proportion was calculated on saturated surface dry (SSD) condition of aggregates. Workability of fresh concrete was selected as $125-130 \mathrm{~mm}$ slump value for high workable concrete. Based on codal provisions of IS 456: 2000 and IS 10262: 2009, design mix proportions for M20 grade concrete for different ingredient compositions were calculated.

In nominal mix(Control Mix) M20 grade concrete, graded angular aggregate of nominal size $20 \mathrm{~mm}$, zone II river sand, 43 grade OPC were used in conventional ratio 1.00 (cement) : 1.5 (sand) : 3.0 (CA). For required workability, w/c was maintained as 0.45 . Density and cement content of the fresh concrete were found $23.45 \mathrm{kN} / \mathrm{m}^{3}$ and $390.83 \mathrm{~kg} / \mathrm{m}^{3}$ respectively.

\subsection{Cement}

The cement used in this experimental study for production of concrete was ordinary Portland cement 
43 grade manufactured in INDIA and conformed to requirements specified in IS 8112-2013.

4.3 In a nominal mix concrete 43 grade OPC were used in conventional ratio 1.00 (cement): 1.5 (sand): 3.0 (CA) and super plasticizer admixture $2 \%$ of weight of cement. The ratio of water to cement is fixed to 0.45 and slump is taking constant between $120-130 \mathrm{~mm}$.

\begin{tabular}{|l|l|l|l|l|l|l|l|l|l|l|l|}
\hline $\begin{array}{l}\text { Fresh } \\
\text { concrete } \\
\text { properties }\end{array}$ & G0 & G1 & G2 & G3 & G4 & G5 & G6 & G7 & G8 & G9 & G10 \\
\hline $\begin{array}{l}\text { Slump in } \\
\text { mm }\end{array}$ & 130 & 130 & 130 & 130 & 130 & 130 & 130 & 125 & 125 & 125 & 120 \\
\hline $\begin{array}{l}\text { Temperature } \\
\mathbf{o}_{\mathbf{C}}\end{array}$ & 24 & 24 & 24 & 24 & 24 & 24 & 24 & 24 & 24 & 24 & 24 \\
\hline $\begin{array}{l}\text { W/C Ratio } \\
\text { Curing }\end{array}$ & 0.45 & 0.45 & 0.45 & 0.45 & 0.45 & 0.45 & 0.45 & 0.45 & 0.45 & 0.45 & 0.45 \\
\hline method & Water & Water & Water & Water & Water & Water & Water & Water & Water & Water & Water \\
\hline
\end{tabular}

Table 6 :Fresh concrete properties

\begin{tabular}{|l|l|l|}
\hline S No & Symbol & \multicolumn{1}{|c|}{ Notification } \\
\hline $\mathbf{1}$ & G0 & Control Mix M 20 \\
\hline $\mathbf{2}$ & G1 & Control Mix M 20+ 5\% waste glass powder replaced with FA \\
\hline $\mathbf{3}$ & G2 & Control Mix M 20+ 10\% waste glass powder replaced with FA \\
\hline $\mathbf{4}$ & G3 & Control Mix M 20+ 15\% waste glass powder replaced with FA \\
\hline $\mathbf{5}$ & G4 & Control Mix M 20+ 20\% waste glass powder replaced with FA \\
\hline $\mathbf{6}$ & G5 & Control Mix M 20+ 25\% waste glass powder replaced with FA \\
\hline $\mathbf{7}$ & G6 & Control Mix M 20+ 30\% waste glass powder replaced with FA \\
\hline $\mathbf{8}$ & G7 & Control Mix M 20+ 35\% waste glass powder replaced with FA \\
\hline $\mathbf{9}$ & G8 & Control Mix M 20+40\% waste glass powder replaced with FA \\
\hline $\mathbf{1 0}$ & G9 & Control Mix M 20+45\% waste glass powder replaced with FA \\
\hline $\mathbf{1 1}$ & G10 & Control Mix M 20+ 50\% waste glass powder replaced with FA \\
\hline
\end{tabular}

\section{Table 7 : notification of symbol}
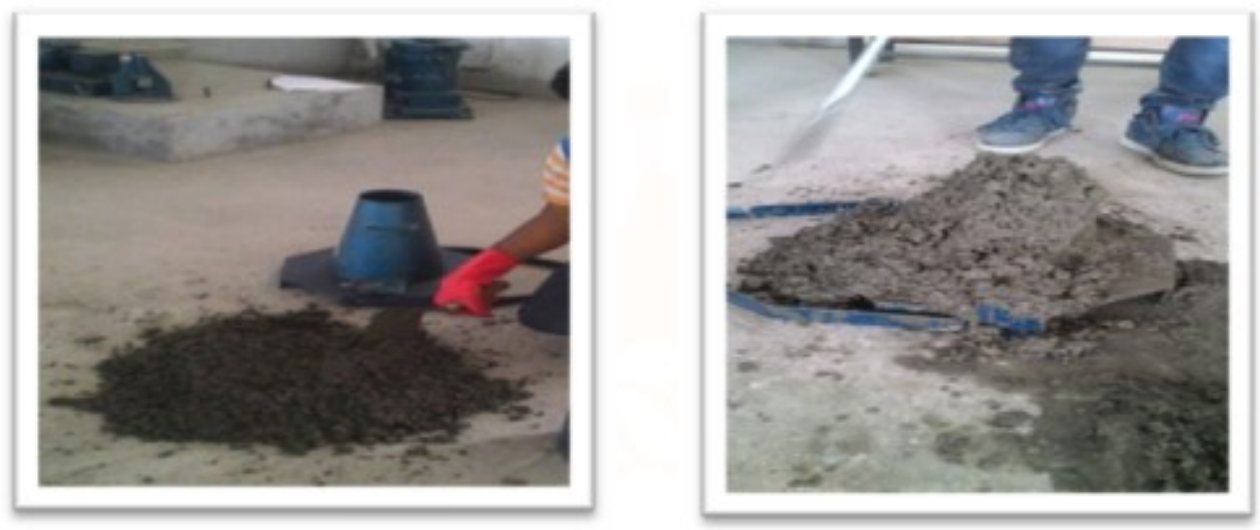

Figure 6: slump value test 

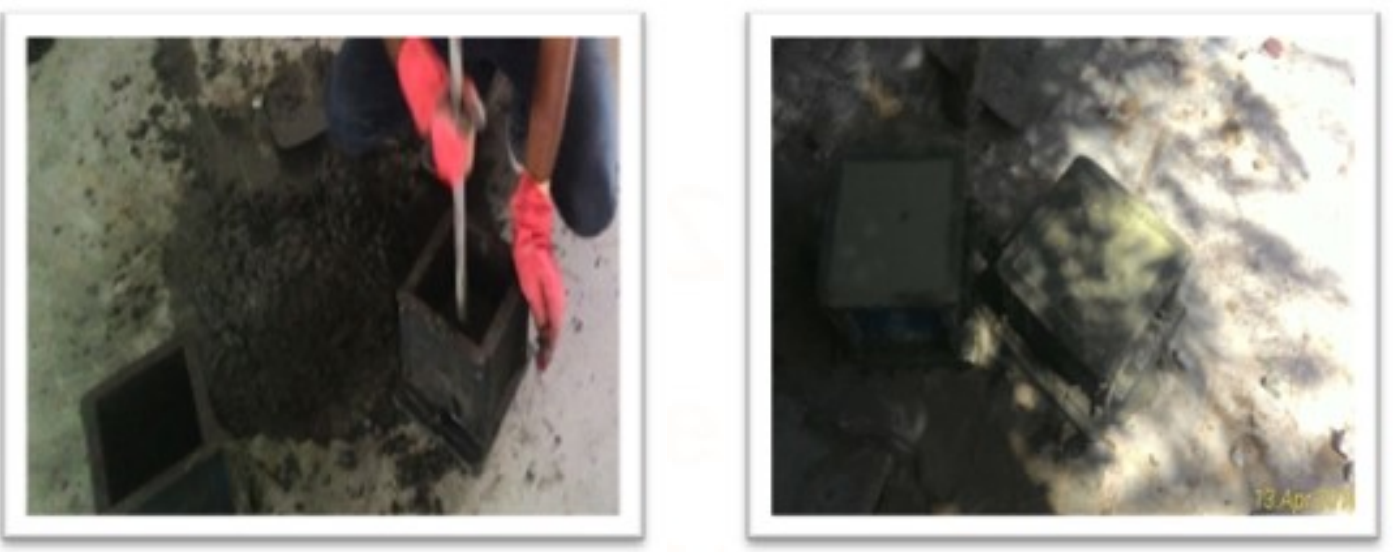

Figure 7 : compaction of concrete cube
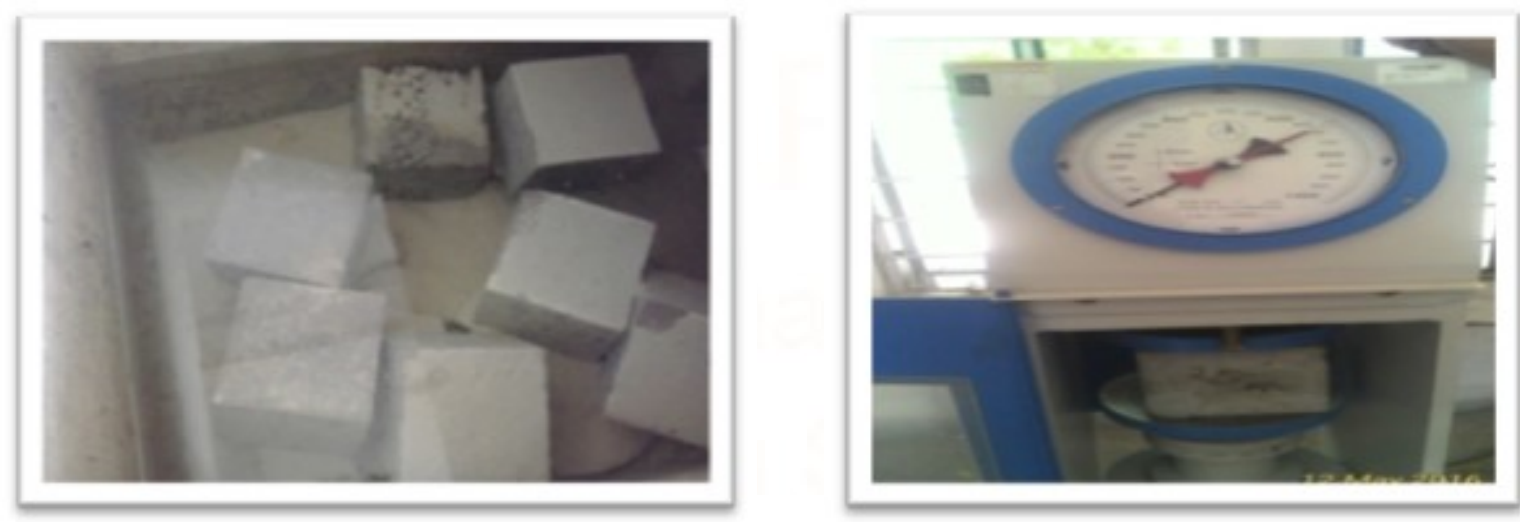

Figure 8: curing and testing of cube

\section{Results and discussion}

5.1 Compressive Strength of concrete cube

Concretes containing glass powder as fine aggregates, with a mixing ratio of $5 \%, 10 \%, 15 \%, 20 \%, 25 \%, 30 \%$, $35 \%, 40 \%, 45 \%$ and $50 \%$. In this experimental study it was seen that there is a increasing trend of compressive strength than that of plain concrete with the addition of waste glass powder up to a optimum percentage of $25 \%$ of 28 days.

\begin{tabular}{|c|c|c|c|c|}
\hline Mix name & Symbol & $\begin{array}{c}3 \text { days } \\
\text { strength } \\
\text { (MPa) }\end{array}$ & $\begin{array}{c}7 \text { days } \\
\text { strength } \\
\text { (MPa) }\end{array}$ & $\begin{array}{c}28 \text { days } \\
\text { strength } \\
\text { (MPa) }\end{array}$ \\
\hline Control Mix M 20 & G0 & 18.67 & 22 & 26.89 \\
\hline Control Mix M 20+ 5\% waste glass powder replaced with FA & G1 & 18.7 & 22.44 & 27.33 \\
\hline Control Mix M 20+10\% waste glass powder replaced with FA & G2 & 18.74 & 22.78 & 28 \\
\hline Control Mix M 20+15\% waste glass powder replaced with FA & G3 & 18.79 & 23.98 & 28.44 \\
\hline Control Mix M 20+ $20 \%$ waste glass powder replaced with FA & G4 & 18.81 & 24 & 28.89 \\
\hline Control Mix M 20+ 25\% waste glass powder replaced with FA & G5 & 19 & 24.96 & 30 \\
\hline Control Mix M 20+30\% waste glass powder replaced with FA & G6 & 18.11 & 24 & 28.89 \\
\hline Control Mix M 20+35\% waste glass powder replaced with FA & G7 & 16.23 & 23.6 & 27.11 \\
\hline Control Mix M 20+ $40 \%$ waste glass powder replaced with FA & G8 & 16.45 & 22 & 26.67 \\
\hline Control Mix M 20+45\% waste glass powder replaced with FA & G9 & 14.67 & 21.09 & 26.22 \\
\hline Control Mix M 20+50\% waste glass powder replaced with FA & G10 & 14 & 20 & 24.22 \\
\hline
\end{tabular}


Table 8: Characteristic strength of concrete in MPa

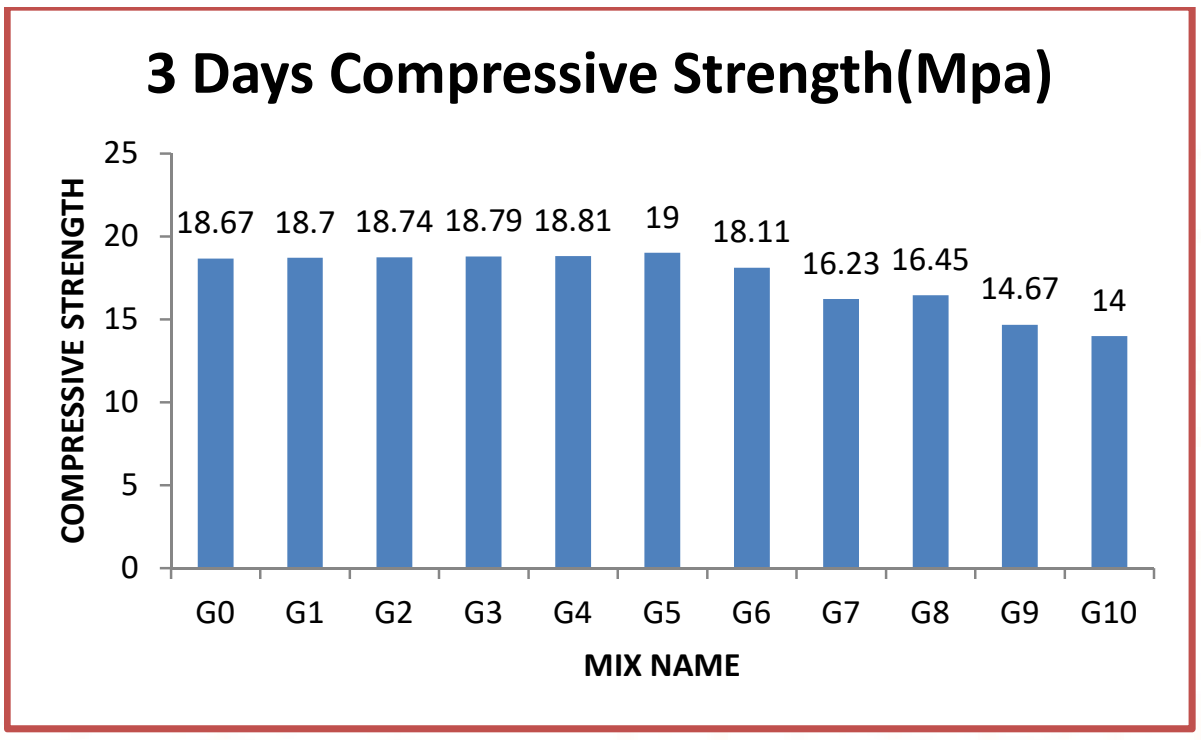

Figure 9: 3 Days compressive strength

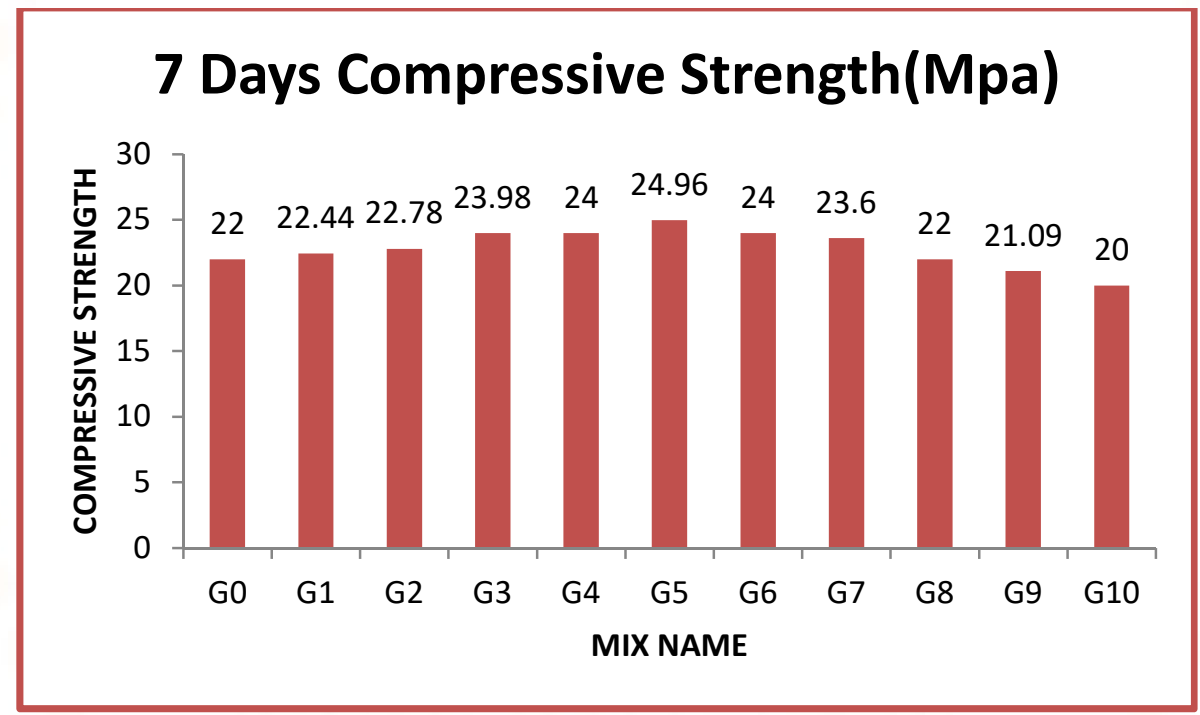

Figure 10: 7 Days compressive strength

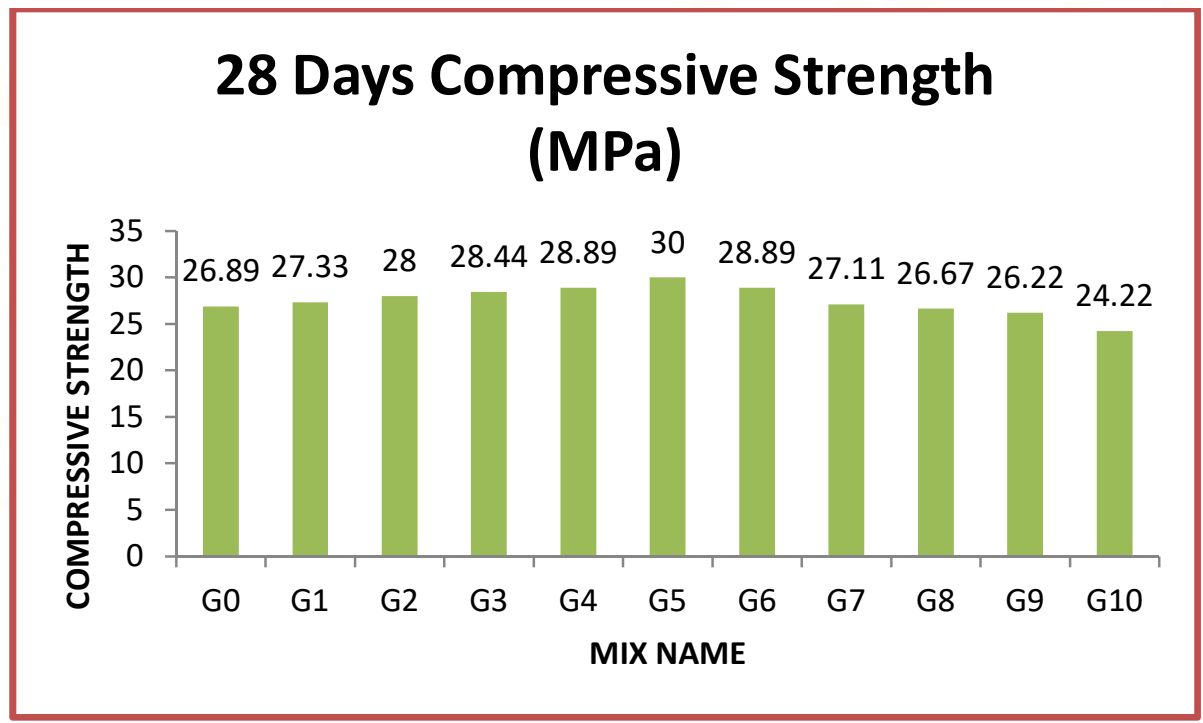


Figure 11: 28 Days compressive strength

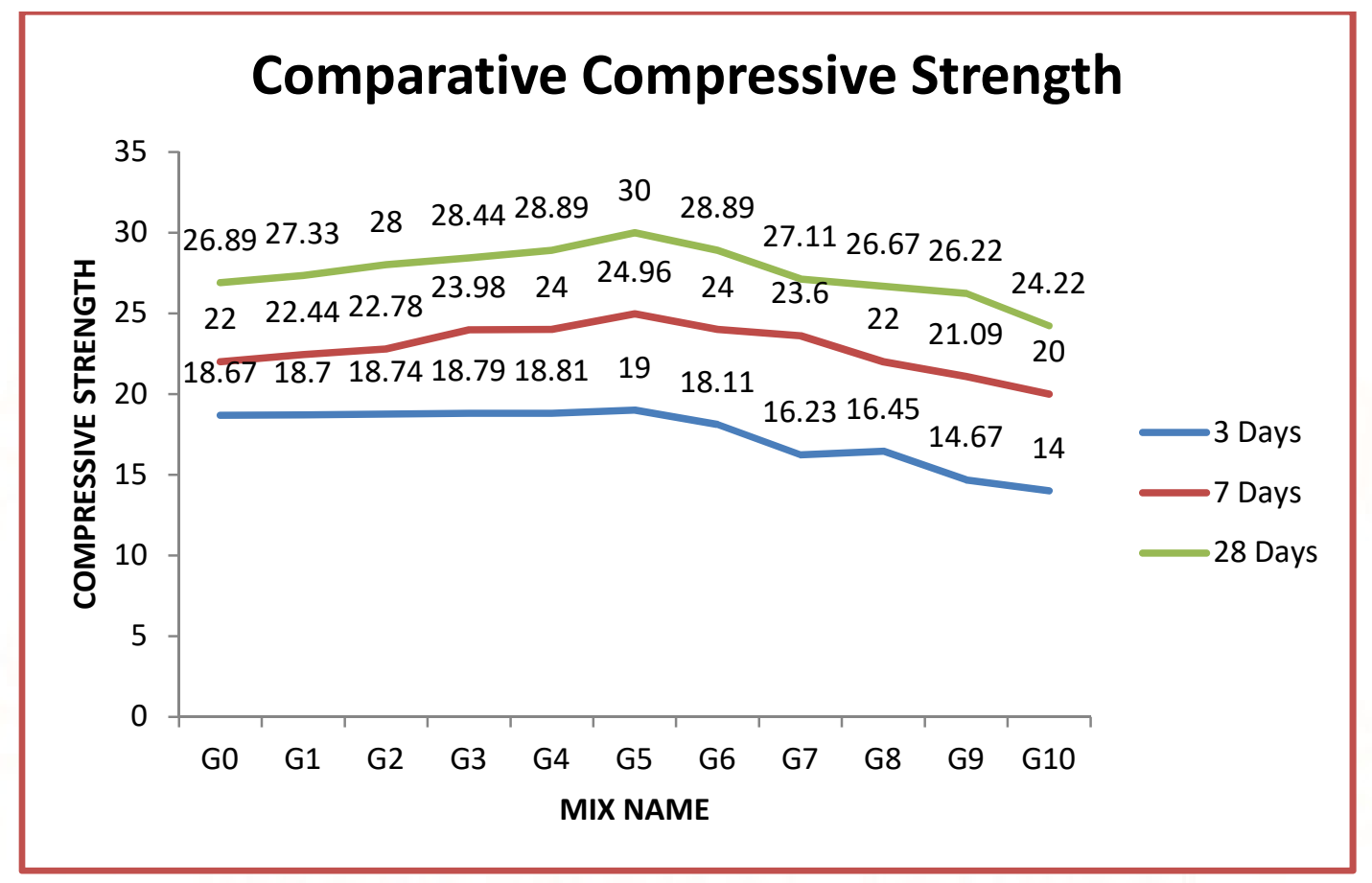

Figure 12: Comparative Compressive Strength

This experimental study was found optimum percentage of glass waste power was found to be $25 \%$ by weight of fine aggregate at which addition of glass waste power increase the cube compressive strength of concrete in 28 day to an extent of $11.56 \%$ which is approximately equal to M 30 grade of concrete. Results proved that adding of glass waste power with $25 \%$ of weight of fine aggregate leads to improvements in compressive strength. Hence, glass waste power may be used as a way for safe disposal of waste glass.

\section{References:}

[1] IS 456-2000- "Plain and reinforced concrete code of practice (fourth revision)"

[2] IS 383-1970- "specification for coarse and fine aggregates from natural sources for concrete (second revision)"

[3] IS8112-2013-“ordinary portland cement,43 grade specification ( second revision )"

[4] IS 3025(1-56 parts) -"Methods of sampling and test (physical and chemical) for water and wastewater"

[5] IS 3025(1-56 parts) -"Methods of sampling and test (physical and chemical) for water and wastewater"

[6]AS 1379 "Specification and supply of concrete Standards Australia"
[7] ASTM C-94 "Standard Specification for Ready mix Concrete-1996"

[8]ACI 318M-08, "Building Code Requirements for Structural Concrete and Commentary"

[9]ASTM 1602M-06 "Standard Test Method for Mixing Water Used in the Production of Hydraulic Cement Concrete"

[10]EN 1008 "Mixing water for concrete specification for sampling, testing and assessing the suitability of water, including water recovered from processes in the concrete industry, as mixing water for concrete"

[11]Shetty M.S. - "Concrete technology (theory \& practice), S. chand and company" [12]Steinour HH,_Concrete Mix Water -How Impure Can It Be Portland Cement Association Journal Research and Development Laboratories, 3, No. 3 pp. 32-50

Sept.

1960

[13] IS2386-1963- "methods of test for aggregates for concrete (part iv mechanical properties)" [14] IS9103-1999- "concrete admixtures specification (first revision)" [15] Singh Parbin- "civil engineering material-katson publishers of engineering new Delhi" [16] IS516-1959- "methods of tests for strength of concrete"

[17] IS1199-1959- "methods of sampling and analysis of concrete (eleventh reprint)" 
[18] IS8112-2013- "ordinary portland cement,43 grade specification ( second revision )"

[19] IS269-2013- "specification foe 33 grade ordinary portlad cement" [20] IS12269-2013- "specification for ordinary portland cement (first revision)" [21] IS8041-1990- "specification for rapid hardening portland cement (second revision)" [22] IS455-1989- "specification for Portland slag cement (forth revision)" [23] IS1489 (part i-ii)-1991-“specification for Portland pozzolana cement (third revision)" [24] IS6452-1989-"specification for high alumina cement for structural use (second revision)" [25] IS8043-1991-"specification for hydrophobic portland cement (second revidion)" [26] IS6909-1990-"specification for super sulphated cement (reaffirmed 2011)" [27] IS 12600-1989-“specification for low heat portland cement (reaffirmed 2014)" [28] IS4031-1988- ".methods of physical tests for hydraulic cement (Part 1-6)" 